\title{
NOTE
}

\section{Estimation of Testosterone Binding Capacity in the Serum with Hydrophobic Resin}

\author{
HiRoko KAWAMOTO \\ Division of Chemistry, Institute of Steroid Research, \\ Tottori University School of Medicine, Yonago, Tottori, 683
}

\section{Synopsis}

\begin{abstract}
A method for the estimation of the serum testosterone binding capacity (TeBC) using hydrophobic resin, Amberlite XAD-2, was developed. The serum was incubated with a saturating amount of testosterone $-1,2{ }^{3} \mathrm{H}$ at $15^{\circ} \mathrm{C}$, unbound testosterone was adsorbed to the resin and the ${ }^{3} \mathrm{H}$-radioactivity remaining in the supernatant fluid was counted. Under these conditions, the normal levels and their standard deviations were $15.08 \pm 3.39 \mathrm{ng} / \mathrm{m} l \quad(\mathrm{n}=7)$ for male and $35.06 \pm 3.56 \mathrm{ng} / \mathrm{ml}(\mathrm{n}=6)$ for female respectively. Precision of the method was $6.29 \%$. TeBC in the third month of pregnancy was approxinately 1.5 times more than that of non-pregnant women, and approximately 3 to 5 times in the tenth month.
\end{abstract}

In 1959, Slaunwhite and Sandberg first reported the protein in serum which binds testosterone, and it was named "Testosterone binding globulin (TeBG)". A number of studies on the estimation of TeBG have been carried out using the equilibrium dialysis (Pearlman et al., 1967; Pearlman and Crepy, 1967), gel filtration (De Moor et al., 1962), and other protein fractionation procedures, such as electrophoresis and column chromatography. Recently, a relative simple procedure with ammonium sulfate precipitation method (Rosner, 1972) was also reported.

In the present study, testosterone binding capacity (TeBC) was assayed with hydrophobic resin (Amberlite XAD-2) which had been developed for the estimation of serum cortisol binding capacity (CBC) by Usui and Kawamoto (1971).

Received for publication August 4, 1975 .

\section{Materials and Methods}

\section{Principle}

TeBG in the serum is saturated by incubating the serum in the presence of the saturating amount of testosterone-1,2-3 $\mathrm{H}$, unbound testostrone is removed by shaking with the hydrophobic resin, Amberlite $\mathrm{XAD}-2$, and the radioactivity of testosterone- $1,2-{ }^{3} \mathrm{H}$ remaining in the supernatant fluid is measured in a liquid scintillation counter. The amount of testosterone bound $(\mathrm{ng} / \mathrm{ml})$ is referred to as the testosterone binding capacity ( $\mathrm{TeBC}$ ) in the serum.

\section{Materials}

1) Testosterone solution: Unlabelled testosterone $(10 \mu \mathrm{g} / \mathrm{ml})$ and testosterone- $1,2{ }^{3} \mathrm{H}(0.4 \mu \mathrm{Ci} / \mathrm{m} l$. The Radiochemical Centre, Amersham, England) were dissolved in methanol. This solution was kept in a refrigerator.

2) Amberlite XAD-2 (diameter 0.30-0.45 mm, Organo Co. Ltd.): The resin was washed by decantation with a large volume of distilled water to eliminate fine particles.

3) Scintillation fluid: $4.0 \mathrm{~g}$ of PPO (2,5-diphenyloxazole) and $0.5 \mathrm{~g}$ of POPOP (1,4-bis [2-(5-phenyloxazolyl)]benzene) were dissolved in $1,000 \mathrm{ml}$ of toluene. This solution was stored in a dark place. 


\section{Procedure}

Two $\mathrm{ml}$ of the serum to be analyzed was placed in a $50 \mathrm{~m} l$ round bottom flask, mixed well with 1.8 $\mathrm{m} l$ of distilled water and $0.2 \mathrm{ml}$ of testosterone solution, and the mixture was kept standing for 10 min. at room temperature. The flask was placed in an incubator equilibrated at $15^{\circ} \mathrm{C}$ and allowed to stand for $5 \mathrm{~min}$. Three $\mathrm{ml}$ of Amberlite XAD-2 was added to the flask and the mixture was incubated for $15 \mathrm{~min}$ by shaking. At the end of the incubation, $3.0 \mathrm{ml}$ of the supernant fluid of the incubation mixture was transferred to a $20 \mathrm{ml}$ test tube and extracted with $6.0 \mathrm{ml}$ of methylene chloride.

After the extraction, $4.0 \mathrm{ml}$ of methylene chloride layer was transferred to a counting vial, and the solvent was evaporated to dryness. The residue was dissolved into $0.2 \mathrm{ml}$ of methanol and $10 \mathrm{ml}$ of the scintillation fluid was added. The determination of the ${ }^{3} \mathrm{H}$-radioactivity was carried out in a liquid scintillation spectrometer (Packard Model 3380, U.S.A.).

Two $\mathrm{m} l$ of distilled water was treated in the same manner and the value obtained was referred to as the blank. For the standard estimation, $20 \mathrm{ng}$ of testosterone were added to $5.0 \mathrm{ml}$ of distilled water and the mixture was incubated at $15^{\circ} \mathrm{C}$ without resin. Three $\mathrm{ml}$ from the mixture was extracted and the radioactivity of tritium was counted as described above.

TeBC is expressed according to the following equation:

$$
\begin{aligned}
& \text { TeBC }=\frac{A-B}{S-B} \times \frac{W}{V}(\mathrm{ng} / \mathrm{m} l) \\
& B: \text { Count of the blank }(\mathrm{cpm}) \\
& A: \text { Count of the sample }(\mathrm{cpm}) \\
& S: \text { Count of the standard }(\mathrm{cpm}) \\
& V: \text { Volume of serum }(2.0 \mathrm{~m} l) \text { used for estimation } \\
& W: \text { Weight of the standard testosterone added } \\
& \quad(2.0 \mathrm{ng})
\end{aligned}
$$

\section{Results}

\section{Protocol for assay conditions}

1) Amount of testosterone added

Fig. 1 shows the amount of testosterone required for saturation of TeBG. The amount of bound testosterone was increased with the amount of loaded testosterone and reached the plateau after $400 \mathrm{ng}$ testosterone per $\mathrm{m} l$ of serum. From this observation $1 \mu \mathrm{g}$ testosterone is loaded per $\mathrm{m} l$ of serum for the estimation of $\mathrm{TeBC}$ under the condition employed in the present study.
2) Effect of temperature upon loading of testosterone

The effect of temperature on saturation of TeBG with testosterone was studied. A slight increase of $\mathrm{TeBC}$ was observed, when the temperature was raised from $15^{\circ} \mathrm{C}$ to $40^{\circ} \mathrm{C}$. Ten minutes were required to obtain complete saturation of TeBG with testosterone at room temperature.

3) Amount of resin

To remove the unbound and albumin bound testosterone, more than $3 \mathrm{~m} l$ of resin were required. Addition of the excess amount of resin was not preferable because of difficulty to separate $3 \mathrm{~m} l$ of the supernatant fluid.

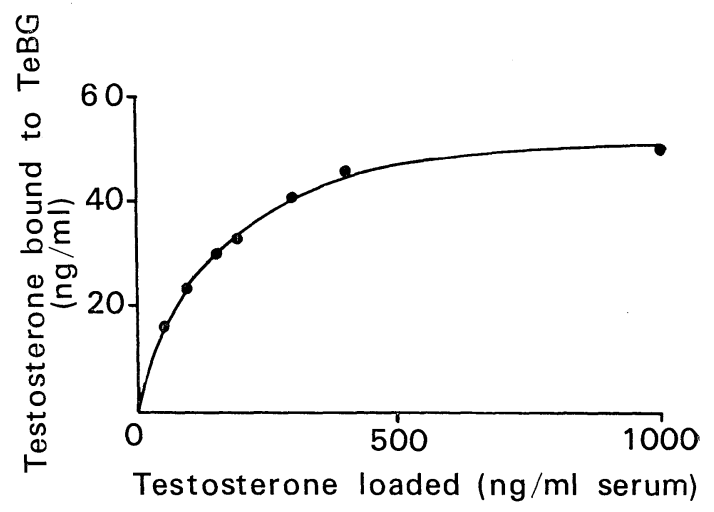

Fig. 1. Amount of testosterone required to saturate TeBG in the serum.

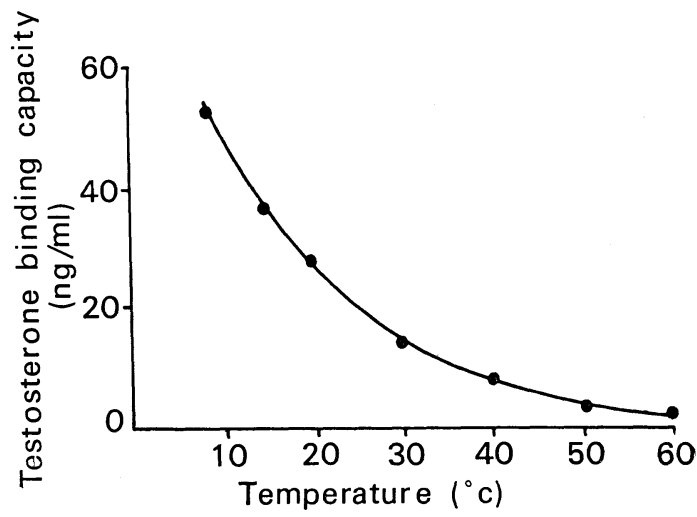

Fig. 2. Effect of the incubation temperature with resin on the testosterone binding capacity in the serum. 
4) Effect of the incubation temperature The effect of the incubation temperature with resin on $\mathrm{TeBC}$ in the serum was depicted in Fig. 2. A rapid decline in the binding capacity by increasing temperature was observed.

5) Effect of the incubation time with resin

In the time course of incubation, a plateau was observed between 10 to $20 \mathrm{~min}$. The longer incubation removed more testosterone from TeBG. In this method, incubation of $15 \mathrm{~min}$ at $15^{\circ} \mathrm{C}$ was adopted.

6) Volume of the serum to be analyzed

A linear relationship between $\mathrm{TeBC}$ and the volume of serum was observed, but the regression line did not intersect the origin (Fig. 3). In the present study, $2 \mathrm{~m} l$ of serum was adopted for the routine analysis. When a smaller amount of the serum was analyzed, the smaller value of TeBC was observed than that obtained under the standard assay conditions.

7) Effect of albumin on $\mathrm{TeBC}$

To examine the effect of albumin on TeBC estimation, bovine serum albumin solution $(0-3 \% \mathrm{w} / \mathrm{v}$ in $0.9 \% \mathrm{NaCl})$ was treated in the same manner as the serum used for the TeBC estimation. No significant influence in $\mathrm{TeBC}$ by any concentration of bovine albumin solution was detected.

\section{Properties of $T e B G$}

1) Heat stability

To study the heat stability of TeBG, the serum was treated at the settled temperature for $10 \mathrm{~min}$ prior to the TeBC determination. No significant changes in $\mathrm{TeBC}$ in the serum treated at the temperature lower than $50^{\circ} \mathrm{C}$ were observed, but marked a decrease of TeBC was observed by the treatment at $60^{\circ} \mathrm{C}$. After $30 \mathrm{~min}$ treatment at $60^{\circ} \mathrm{C}$, about $80 \%$ of the activity was destroyed.

2) Effect of $\mathrm{pH}$ on $\mathrm{TeBC}$ estimation

Fig. 4 shows the effect of $\mathrm{pH}$ on $\mathrm{TeBC}$ determination. After the serum was dialyzed against the $0.9 \% \mathrm{NaCl}$ solution overnight at $4^{\circ} \mathrm{C}$, the dialyzed samples were diluted with the buffer solution of appropriate $\mathrm{pH}$ instead of distilled water and subjected to the TeBC estimation. In the alkaline media, TeBC was relatively constant, however in acidic media (lower than $\mathrm{pH} 5$ ) $\mathrm{TeBC}$ decreased significantly.

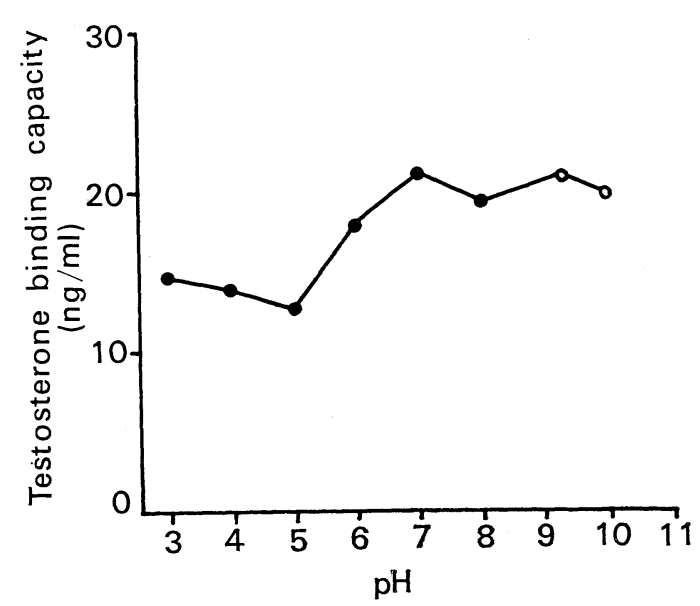

Fig. 4. Effect of $\mathrm{pH}$ on testosterone binding capacity. Closed circle : $0.1 \mathrm{M}$ citrate buffer; Open circle: $0.1 \mathrm{M}$ glycine buffer.
Fig. 3. Correlation between the volume of serum and testosterone binding capacity.

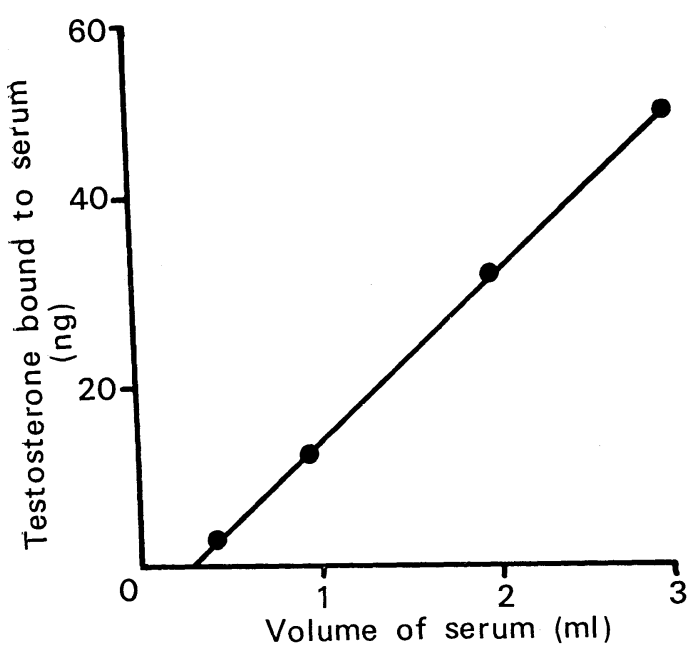


3) Effect of various steroids on TeBC estimation

Testosterone-1,2- ${ }^{3} \mathrm{H}$ and non-radioactive steroids were added simultaneously to the serum, and TeBC determination was performed. The result was expressed as the per cent binding of the control in which only testosterone was added for the determination.

As shown in Table 1, the binding of testosterone to the serum protein was influenced by the addition of all the steroids examined. The effect of estradiol-17 $\beta$ was most profound. TeBC was decreased to $40-50 \%$ of that of the control by the

Table 1. Effect of various steroids on the testosterone binding capacity.

\begin{tabular}{lcc}
\hline & \multicolumn{2}{c}{ relative binding capacity $(\%)$} \\
\cline { 2 - 3 } & \multicolumn{2}{c}{$\begin{array}{c}\text { concentration of the steroid } \\
\text { solution added }(\mu \mathrm{g} / \mathrm{m} l)\end{array}$} \\
steroids & 10 & 100 \\
\hline without steroid & 100.0 & 100.0 \\
cortisol & 70.0 & 57.3 \\
corticosterone & 75.7 & 59.0 \\
androsterone & 65.7 & 76.5 \\
dehydroepiand rosterone & 70.4 & 65.2 \\
estradiol-17 $\beta$ & 49.6 & 39.5 \\
estriol & 62.8 & 67.7
\end{tabular}

To $2.0 \mathrm{~m} l$ of serum, $0.2 \mathrm{~m} l$ of $10 \mu \mathrm{g} / \mathrm{m} l$ testosteron ${ }^{3} \mathrm{H}$ solution and $0.1 \mathrm{~m} l$ of steroid solution under testing were added, and $\mathrm{TeBC}$ was determined.

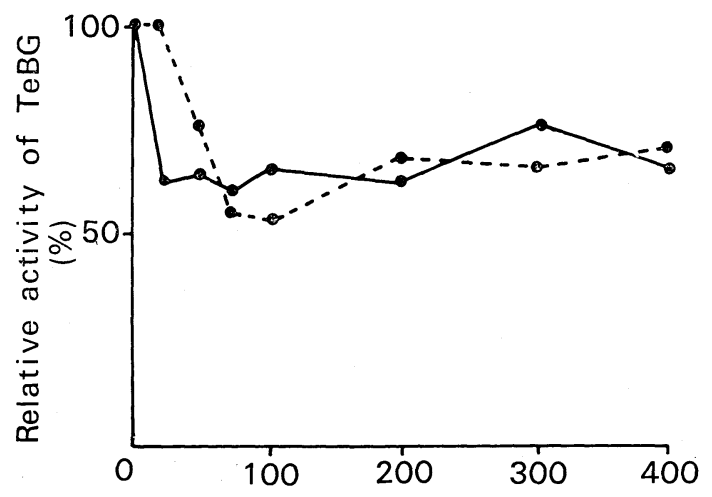

Amount of steroids $(\mu \mathrm{g} / 100 \mathrm{ml}$ serum)

Fig. 5. Effect of supplementation of cortisol and estradiol-17 $\beta$ on TeBC estimation. Solid line: addition of cortisol; Broken line: addition of estradiol- $17 \beta$. addition of estradiol-17 $\beta$. The dose-response relationship of the testosterone binding to the concentration of either estradiol $17 \beta$ or cortisol added was depicted in Fig. 5. The addition of $20 \mu \mathrm{g} / 100 \mathrm{~m} l$ cortisol diminished $\mathrm{TeBC}$ to $60 \%$ and by the addition of $100 \mu \mathrm{g} / 100 \mathrm{~m} l$ estradiol- $17 \beta$, TeBC was decreased to $50 \%$ of that of the control.

3. Reproducibility of the method

Ten repeated estimation by the present method gave $21.3 \pm 1.3 \mathrm{ng} / \mathrm{m} l$ (mean \pm S.D. : range $19.0-23.5 \mathrm{ng} / \mathrm{ml}$ ) and the coefficient of variation was $6.29 \%$.

\section{Normal range of $T e B C$}

TeBC in 13 healthy adults was $15.08 \pm$ $3.39 \mathrm{ng} / \mathrm{ml}$ (mean and S.D. of 7 males) ranging from 11.2 to $20.1 \mathrm{ng} / \mathrm{m} l$, and 35.06 $\pm 3.56 \mathrm{ng} / \mathrm{m} l$ ( 6 females) ranging from 30.7 to $40.4 \mathrm{ng} / \mathrm{ml}$, respectively. A significant difference in $\mathrm{TeBC}$ was observed between the normal males and females.

5. TeBC in the serum of pregnant women High TeBC in the serum of pregnant women has been studied. As shown in Fig. 6, TeBC in the third month of pregnancy

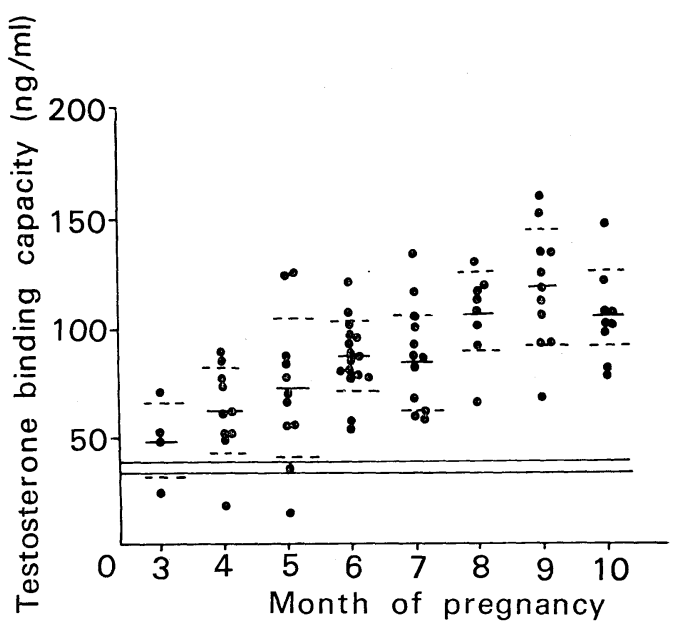

Fig. 6. Testosterone binding capacity in the serum from pregnant women. Solid bar: mean; Dotted bar: \pm S.D.; Solid line: normal range of nonpregnant women. 
was significantly increased when compared with that of non-pregnant women (mean of TeBC in the third month was $49.4 \mathrm{ng} / \mathrm{ml}$ ). With the progress of pregnancy, the increase in $\mathrm{TeBC}$ became more pronounced.

\section{Discussion}

In recent years, various microanalytical methods for determination of steroid hormones using radiochemical or radioimmunological techniques have been developed and the quantitative determination of steroid hormones in the serum has been adopted as routine works for diagnosis of endocrine disorders. The major part of steroid hormones in the serum was observed to be bound to proteins and the concentration of unbound steroid seems to be relatively low, however the latter has been reported to play an important role in the physiological action of steroid hormones (Mauvais-Jarvis et al., 1971; Ruder et al., 1971; Vermeulen et al., 1972). As the affinity of the steroids to serum protein is relatively weak, they are easily extractable from the serum with organic solvents. As steroids extracted with organic solvents from the serum include both protein bound and unbound steroids, the estimated steroid amount is not always proportional to the biological activity of steroids. In this regard, it seems to be important to compare the amount of total steroids with the amount of steroid binding proteins in the serum, in order to assess the amount of biological active steroid hormones in the serum.

The author proposed a simple and reliable method for TeBC estimation for routine laboratory works. The most important process of the assay is to keep the temperature constant during the procedure, since TeBC is markedly affected by the temperature of the incubation with the ligand steroid and resin. In the present method, the assay is carried out in test tubes and the temperature can be kept constant easily. The lower the temperature is, the higher the value of TeBC is. The author adopted temperature at $15^{\circ} \mathrm{C}$, because the temperature was the same as that of cortisol and $\mathrm{CBG}$ estimation in the serum in our laboratory method. Usui and Kawamoto (1971) described a linear correction equation against temperature for CBG estimation when the incubation is carried out at different temperature, but the method cannot be applied for TeBC because of the non-linear relationship between $\mathrm{TeBC}$ and temperature.

Sandberg et al. (1957) pointed out that steroids are bound not only to the specific binding protein but also albumin with low affinity. In the present study, serum albumin does not affect the TeBC estimation at all.

The most troublesome matter in the TeBC assay is the effect of steroids other than testosterone. The effect of estradiol- $17 \beta$ on $\mathrm{TeBC}$ is inhibitory. It inhibits the testosterone binding to the $\beta$-globulin fraction in a competitive manner (Corvol et al., 1971). It was known that $\beta$-globulin fraction also binds to estradiol-17 $\beta$, and the estradiol binding protein seems to be the same protein of TeBG (Westphal, 1971). Therefore the protein is called either "sex hormone binding globulin (SHBG)" or "estradiol and testosterone binding globulin" (Rosner, 1972 ; Corvol, 1971). Another report by De Moor et al. (1962) reveals that CBG also binds testosterone in appreciable amount. Then TeBC estimated by the present method represents not only the binding capacity of TeBG but also the testosterone binding capacity of CBG. This. trouble is not only for this method but also for all other methods reported previously.

TeBC values estimated by the present method are compared with those reported by other investigators in Table 2 . The normal values obtained in the present study is somewhat higher. This difference is mainly due to the difference of incubation tempe- 
Table 2. TeBC in human serum determined by other investigators using various assay methods

\begin{tabular}{|c|c|c|c|c|c|c|c|}
\hline \multirow[t]{2}{*}{ Investigators } & \multicolumn{2}{|c|}{ Men } & \multicolumn{2}{|c|}{$\begin{array}{l}\text { Non-pregnant } \\
\text { women }\end{array}$} & \multicolumn{2}{|c|}{$\begin{array}{l}\text { Pregnant } \\
\text { women }\end{array}$} & \multirow[t]{2}{*}{ Method } \\
\hline & Mean & S.D. & Mean & S.D. & Mean & S.D. & \\
\hline Rosner $(1972)^{*} 1$ & 9.3 & 3.1 & 18.5 & 5.2 & 119 & 28.0 & $\left(\mathrm{NH}_{4}\right)_{2} \mathrm{SO}_{4}$ precipitation method \\
\hline Vermeulen $(1969) * 1$ & 13.1 & 1.2 & 21.5 & 2.3 & 94 & $-* 3$ & Equilibrium dialysis \\
\hline Corvol $(1971) * 1$ & 4.9 & 1.2 & 14.2 & 8.1 & 109 & 17.0 & Polyacrylamide electrophoresis \\
\hline Tulchinsky $(1973) * 1$ & 10.3 & 3.6 & 25.8 & 9.0 & 157 & 29.0 & Competitive ligand assay \\
\hline Rosenfield $(1971)^{*} 2$ & 9.7 & 2.5 & 18.9 & 6.2 & $-* 3$ & $-* 3$ & Calculation with nomogram \\
\hline This report*2 & 15.1 & 3.4 & 35.1 & 3.0 & 105 & 19.6 & Resin adsorption method \\
\hline $\begin{array}{l}*_{1} \\
*_{2} \\
*_{3}\end{array}$ & $\begin{array}{l}\text { sssed } \\
\text { essed } \\
\text { eport }\end{array}$ & int & 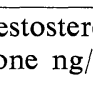 & $\mathrm{ng}$ & & & \\
\hline
\end{tabular}

rature. Although the values are slightly high, discrimination between males and females, and between non-pregnant and pregnant women are apparent, and reproducibility of the method is small (C.V., $6.29 \%$ ) compared with other methods (5.59.6\%, Rosner, 1972; 7-12\%, Tulchinsky, 1973). Therefore the method is applicable enough to the clinical test. The procedure is so simple that a technician can perform more than 50 tests in a single working day.

\section{Acknowledgements}

The author expressed her deep gratitude to Prof. Toshiaki Usui for his kind guidance throughout the course of this work. The author was indebted to the staffs of the Department of Obstetrics and Gynecology of The Tottori University School of Medicine for supplying sera of pregnant women.

\section{References}

Corvol, P. L., A. Chrambach, D. Rodbard and C. W. Bardin (1971). J. Biol. Chem. 246, 3435.
De Moor, P., K. Heirwegh, J. Heremans and $M$. Declerck-Raskin (1962). J. Clin. Invest. 41, 816.

Mauvais-Jarvis, P., O. Crepy and J. P. Bercovici (1971). J. Clin. Endocrinol. Metab. 32, 568.

Pearlman, W. H. and O. Crepy (1967). J. Biol. Chem. 242, 182.

Pearlman, W. H., O. Crepy and M. Murphy (1967). J. Clin. Endocrinol. Metab. 27, 1012.

Rosenfield, R. L. (1971). J. Clin. Endocrinol. Metab. $32,717$.

Rosner, W. (1972). J. Clin. Endocrinol. Metab. 34, 983.

Ruder, H., P. Corvol, J. A. Mahoudeau, G. T. Ross and M. B. Lipsett (1971). J. Clin. Endocrinol. Metab. 33, 382.

Sandberg, A. A., W. R. Slaunwhite and H. N. Antoniades (1957). Rec. Progr. Hormone Res. 13, 209.

Slaunwhite, W. R. and A. A. Sandberg, Jr. (1959). J. Clin. Invest. $38,384$.

Tulchinsky, D. and I. J. Copra (1973). J. Clin. Endocrinol. Metab. 37, 873.

Usui, T. and H. Kawamoto (1971). Clin. Chim. Acta 37, 151.

Vermeulen, A., R. Rubens and L. Verdonck (1972). J. Clin. Endocrinol. Metab. 34, 730.

Vermeulen, A., L. Verdonck, M. van der Straeten and N. Orie (1969). J. Clin. Endocrinol. Metab. 29, 1470 .

Westphal, U. Steroid-Protein Interaction. SpringerVerlag, Berlin, p. 356 (1971). 